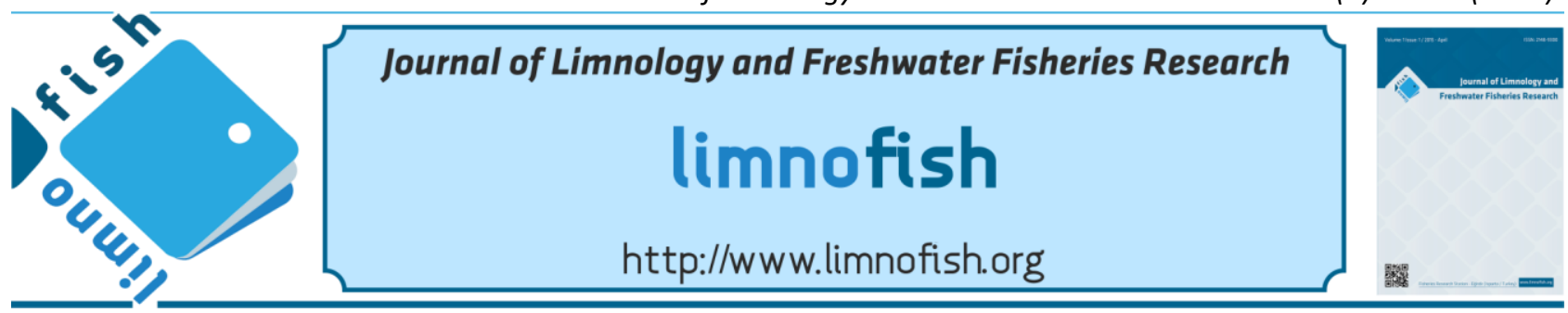

\title{
Determining the Level of Bacteriological Pollution Level in Yağlıdere Stream, Giresun
}

\author{
Tamer AKKAN ${ }^{*}$ (D), Sultan MEHEL ${ }^{2}$ (D), Cengiz MUTLU ${ }^{1}$ \\ ${ }^{1}$ Giresun University, Science and Art Faculty, Biology Department, 28200 Giresun-Turkey \\ ${ }^{2}$ Giresun University, Natural Sciences Institutes, Biology Division, 28200 Giresun-Turkey
}

\section{A B STRACT}

The aim of this study is to investigate the levels of bacteriological water quality and pollution in Yağlidere Stream, Giresun, Turkey. For this purpose, surface water and sediment samples were collected monthly, from five stations between June 2013 and May 2014. A bacteriological assessment of water and sediment samples with a $22^{\circ} \mathrm{C}$ to $37^{\circ} \mathrm{C}$ temperature range, including total coliform bacteria (TC), fecal coliform bacteria $(F C)$, fecal streptococcus $(F S)$, and Escherichia coli were done. Analysis was performed according to standard methods. Water quality and pollution level in Yağlıdere Stream were assessed in accordance with both Turkish legislation and international criteria. The $F C, F S$ and $E$. coli count were detected higher than the reference value at multiple stations in almost every month of the year indicates. In conclusion, it can be said that the bacteriological pollution level of both the surface water and sediment structure of the stream pose a threat to the ecosystem balance.

Keywords: Yağlidere Stream, bacteriological pollution, water quality

\section{ARTICLE INFO}

$\begin{array}{ll}\text { RESEARCH ARTICLE } \\ \text { Received } & \text { :04.08.2018 } \\ \text { Revised } & : 29.11 .2018 \\ \text { Accepted } & : 04.01 .2019 \\ \text { Published } & : 27.08 .2019\end{array}$

DOI:10.17216/LimnoFish.450722

\section{* CORRESPONDING AUTHOR}

biyoloji@yahoo.com

Phone : +90 5353815210

\section{Yağlıdere Çayı (Giresun)'nın Bakteriyolojik Kirlilik Düzeyinin Belirlenmesi}

Öz: Bu çalışmanın amacı Yağlıdere Çayı'nın bakteriyolojik su kalitesi ve kirlilik düzeyinin araştırılmasıdır. Bu amaç için Haziran 2013 ve Mayıs 2014 tarihleri arasında 5 farklı istasyondan aylık olarak su ve sediment örnekleri toplanmıştır. Bakteriyolojik olarak su ve sediment örneklerinden: $22^{\circ} \mathrm{C}$ ve $37^{\circ} \mathrm{C}$ 'deki toplam bakteri sayısı, su örneklerinden: toplam koliform bakteri sayısı $(T K)$, fekal koliform bakteri sayısı $(F K)$, fekal streptokok bakteri sayısı $(F S)$ ve Escherichia coli sayısı tespit edilmiştir. Bütün bu analizler standart metotlara göre gerçekleştirilmiştir. Yağlıdere Çayı'nın bakteriyolojik su kalitesi ve kirlilik düzeyi ulusal ve uluslararası kriterlere göre değerlendirilmiştir. $F K, F S$ ve $E$. coli sayısı, yılın hemen hemen her ayında birden fazla istasyonda referans değerlerden daha yüksek tespit edildi. Sonuç olarak Yağlidere Çayı su ve sediment yapısındaki bakteriyolojik kirlenmenin ekosistemdeki dengeyi tehdit eder düzeyde olduğu söylenebilmektedir.

Anahtar kelimeler: Yağlıdere Çayı, bakteriyolojik kirlilik, su kalitesi

How to Cite

Akkan T, Mehel S, Mutlu C.2019. Determining the Level of Bacteriological Pollution Level in Yağlıdere Stream, Giresun. LimnoFish. 5(2): 83-88. doi: 10.17216/LimnoFish.450722

\section{Introduction}

The quality of freshwater sources plays a very important role in the health of an ecosystem. Water quality refers to the physical, chemical, and biological properties of water that benefit its potential use. In order to determine its quality, water is usually analyzed according to these as well as bacteriological properties (Mutlu and Uncumusaoğlu 2016; Mutlu et al. 2016; Verep et al. 2017; Mutlu and Verep 2018). Deterioration in bacteriological life in an aquatic environment adversely affects other organisms, such as invertebrate animals and fish. Moreover, the bacteriological pollution from sewage can also lead to the harm and loss of valuable aquatic organisms, and may be responsible for the outbreak of water-born diseases (Sipahi et al. 2013; Akkan et al. 2015).

Pollutants entering certain freshwater sources (e.g. streams) harm the natural structure of those sources, which thus leads to water pollution. This situation unfavourably affects aquatic life and can even cause their extinction. Therefore, the state of pollution within our existing freshwater 
resources needs to be known and better understood. In recent years, a sizable number of studies have been carried out on bacteriological pollution levels in Turkish water resources (Yildirim and Vurmay 2017; Altug et al. 2017; Bulbul and Elipek 2017; Akkan 2017). These resources, hence, ought to be continuously monitored, with planning being made for the future, or else irreversible damage will occur. Furthermore, this situation can potentially lead to social, economic, and political problems. In turn, databanks that contain the pollution statistics obtained from local water quality studies need to be established. In due time, water policies should be established by using the data contained in such databanks. If not, the sustainable use of freshwater sources will be impossible to achieve.

The aim of this study is to investigate the bacteriological water quality level in Yağlidere Stream, Giresun, Turkey, as well as to obtain rudimentary data for future planning for this freshwater resource, which discharges to the Black Sea.

\section{Materials and Methods \\ Study Area and Sampling}

Yağlidere Stream is located in the Eastern Black Sea province of Giresun, Turkey. The Yağlidere Stream is formed by the merging of Tohumluk Creek, which is originates in region of Kurteli, with K1lıçlar Creek, which originates from Erimez Mountain. The stream is $70 \mathrm{~km}$ in length, stretches along a narrow valley, and discharges into the Black Sea from the west of the district Espiye, Giresun. It has a water level of $415 \mathrm{hm}^{3}$ and a streamflow data of $96 \mathrm{~m}^{3} / \mathrm{sn}$.

The surface water and sediment samples were collected for bacteriological analysis from five stations between June 2013 and May 2014, on a monthly basis (Figure 1).

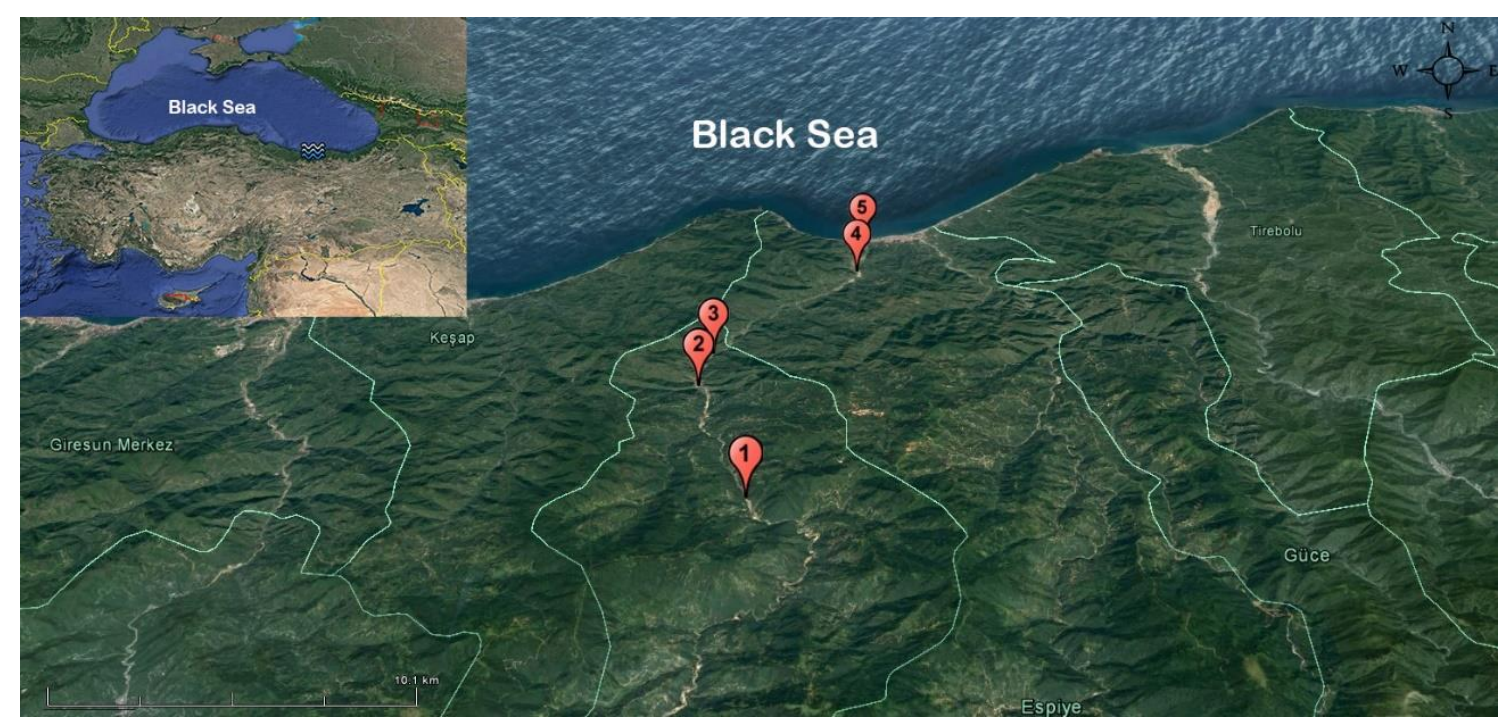

Figure 1. Study Area (adapted from Google Earth)

The surface water samples were then analyzed for total coliform (TC), fecal coliform $(F C)$, fecal streptococcus $(F S)$, and $E$. coli. The sediment samples were also analyzed for their total aerobic bacteria count and mesophilic aerobic bacteria counts. The most-probable-number $(M P N)$ method was used for the $T C, F C$, and $F S$ count in order to determine the bacteriological quality. In addition, the standard plate count method used in order to determine the bacteria count in both the sediment (homogenate rate 1:9) and water samples.

All analyses were performed according to standard methodology (APHA 1992). The results of present study were assessed in accordance with both national and international criteria.

\section{Results}

The $T C$ bacteria count in surface water samples in June was 460- $>1100 M P N / 100 \mathrm{~mL}$, the $F C$ bacteria count was $>240 M P N / 100 \mathrm{~mL}$ at all stations, and the $F S$ bacteria count was 240- >240 MPN/100 mL. In addition, the change in the count of E. coli was determined to be between 80 and $240 M P N / 100 \mathrm{~mL}$. In July, the count of $T C$ bacteria of water samples was determined to be between 11 and $290 \mathrm{MPN} / 100 \mathrm{~mL}$, the $F C$ bacteria count was 19- >240 MPN/100 mL, and the $F S$ bacteria count was $23->240 M P N / 100 \mathrm{~mL}$. E. coli counts varied between 80 and 120 MPN/100 $\mathrm{mL}$. The $T C$ bacteria count within the water samples in August was determined to be between 28 and $120 \mathrm{MPN} / 100 \mathrm{~mL}$, the $F C$ bacteria count 9- >240 $M P N / 100 \mathrm{~mL}$, and the $F S$ bacteria count was between 
9 and $95 M P N / 100 \mathrm{~mL}$, whilst the $E$. coli count was between 18 and 120 MPN/100 mL. In September, the bacterial counts in water samples were determined for $T C$ to be $29->1100 M P N / 100 \mathrm{~mL}$, for $F C$ at all stations to be $>240 M P N / 100 \mathrm{~mL}$, for $F S$ to be 23- >240 MPN/100 mL, and for E. coli to be between 72 and $200 M P N / 100 \mathrm{~mL}$, respectively. In October, the counter were determined for $T C$ to be 75- >1100 MPN/100 mL, for $F C$ to be between 0 and $240 \mathrm{MPN} / 100 \mathrm{~mL}$, for $F S$ to be $23->240$ $M P N / 100 \mathrm{~mL}$, and for $E$. coli to be between 0 and 20 $M P N / 100 \mathrm{~mL}$, respectively. In November, the count of $T C$ bacteria was $16->1100 \mathrm{MPN} / 100 \mathrm{~mL}$, for $F C$ it was between 9 and $240 M P N / 100 \mathrm{~mL}$, for $F S$ bacteria it was 23- >240 MPN/100 mL, and for E. coli it was between 0 and $3 M P N / 100 \mathrm{~mL}$.

In the month of December, the count for $T C$ was $1100->1100 M P N / 100 \mathrm{~mL}$, for $F C$ it was 240- >240 MPN/100 mL, for $F S$ it was 23- >240 $M P N / 100 \mathrm{~mL}$, and for $E$. coli it was between 18 and 47 MPN/100 mL. In January, counts were determined for $T C$ to be $11->1100 M P N / 100 \mathrm{~mL}$, for $F C$ to be 23- >240 MPN/100 mL, for $F S$ to be 23- >240 $M P N / 100 \mathrm{~mL}$, and for $E$. coli to be between 0 and 120 $M P N / 100 \mathrm{~mL}$, respectively. In February, counts for $T C$ were between 28 and $210 M P N / 100 \mathrm{~mL}$, for $F C$ were 240- >240 MPN/100 mL, for $F S$ were 9- > 240 $M P N / 100 \mathrm{~mL}$, and for $E$. coli were between 0 and 3 $M P N / 100 \mathrm{~mL}$, respectively.

For the months of March, April and May, counts for $T C$ were 16- >1100 MPN/100 mL, between 15 and $210 \mathrm{MPN} / 100 \mathrm{~mL}$, and between 16 and 1100 $M P N / 100 \mathrm{~mL}$, for $F C$ (at all stations) were 240 $M P N / 100 \mathrm{~mL},>240 M P N / 100 \mathrm{~mL}$, and 240- >240 $M P N / 100 \mathrm{~mL}$, for $F S$ were between 0 and 240 $M P N / 100 \mathrm{~mL}$, between 23 and $240 M P N / 100 \mathrm{~mL}$, and between 0 and $240 M P N / 100 \mathrm{~mL}$, and for $E$. coli were between 45 and $120 M P N / 100 \mathrm{~mL}$, between 24 and $240 M P N / 100 \mathrm{~mL}$, and between 48 and $180 \mathrm{MPN} / 100 \mathrm{~mL}$, respectively. Results of bacteria counts in surface water samples were shown in Table 1.

Table 1. Results of bacteria counts in surface water samples

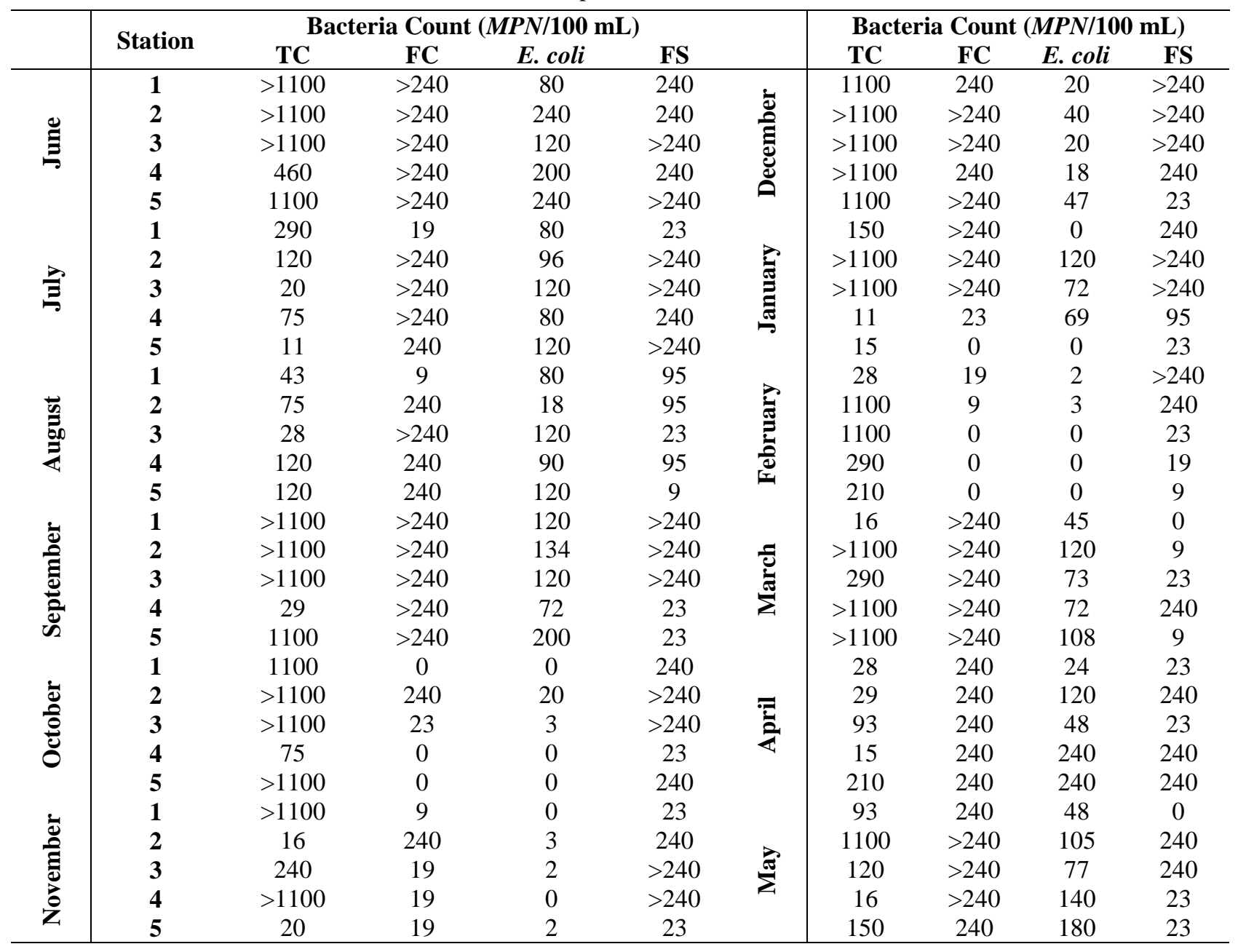


Throughout this study, the bacteria count among aquatic flora (between $22^{\circ} \mathrm{C}$ and $37^{\circ} \mathrm{C}$ ) at $\log _{10}$ for water was found to be 4.2 (3.4-5.5) and 4.0 (2.5-4.8), and for sediment to be 9.2 (3-13.8) and 10.2 (5.1-14.2), respectively (Figures 2, 3, 4 , and 5).

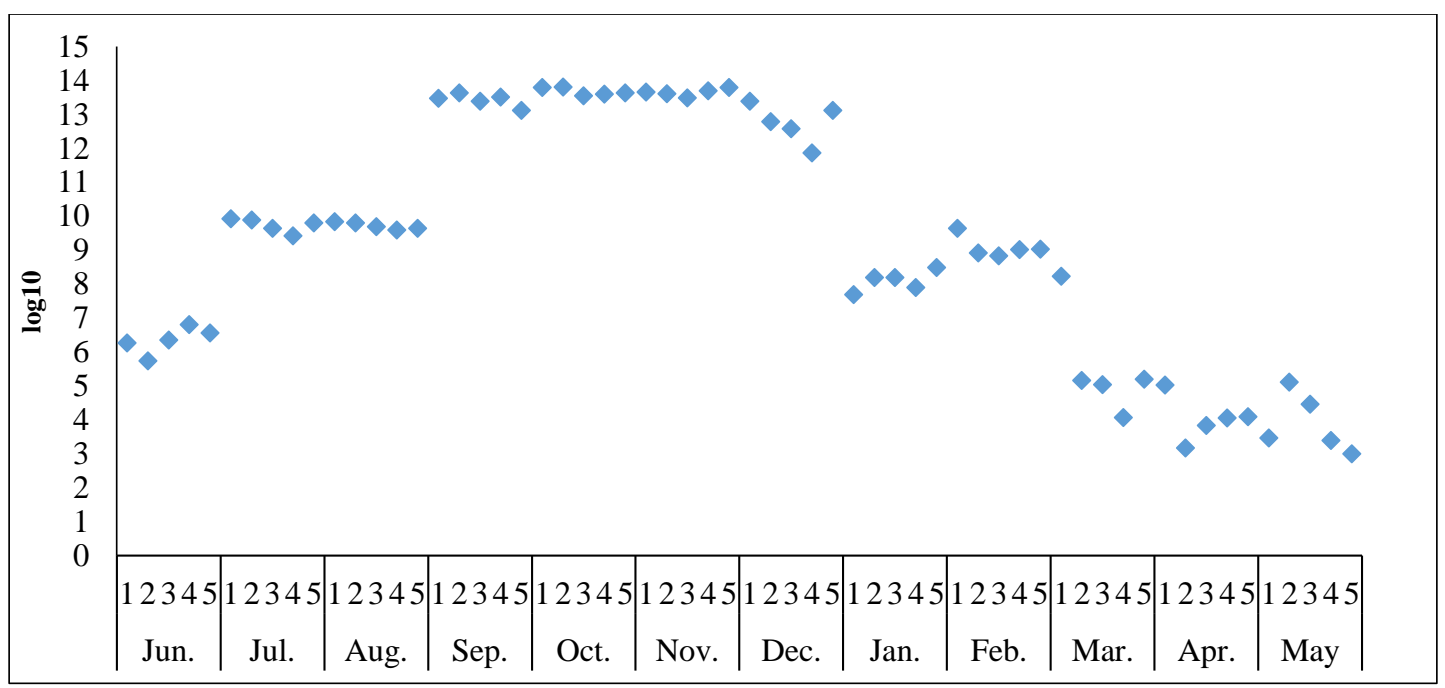

Figure 2. $22^{\circ} \mathrm{C}$ Bacteria Count of Sediment

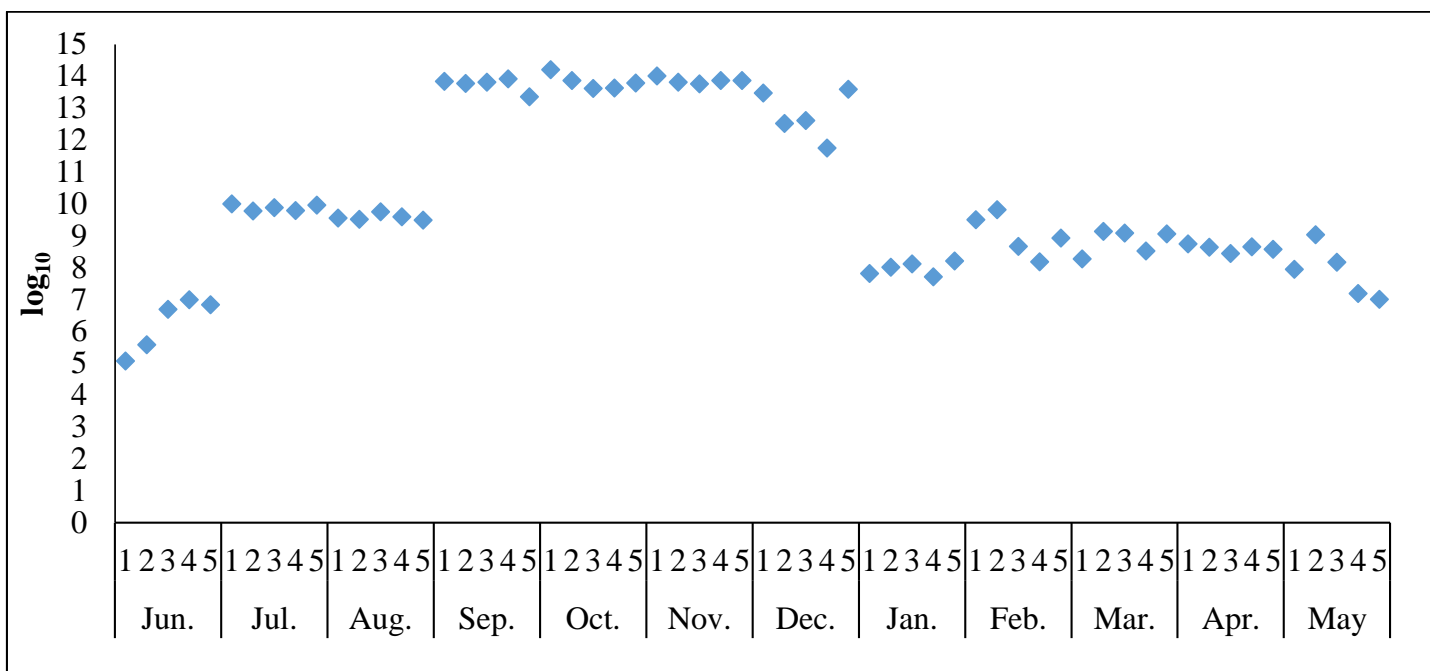

Figure 3. $37^{\circ} \mathrm{C}$ Bacteria Count of Sediment

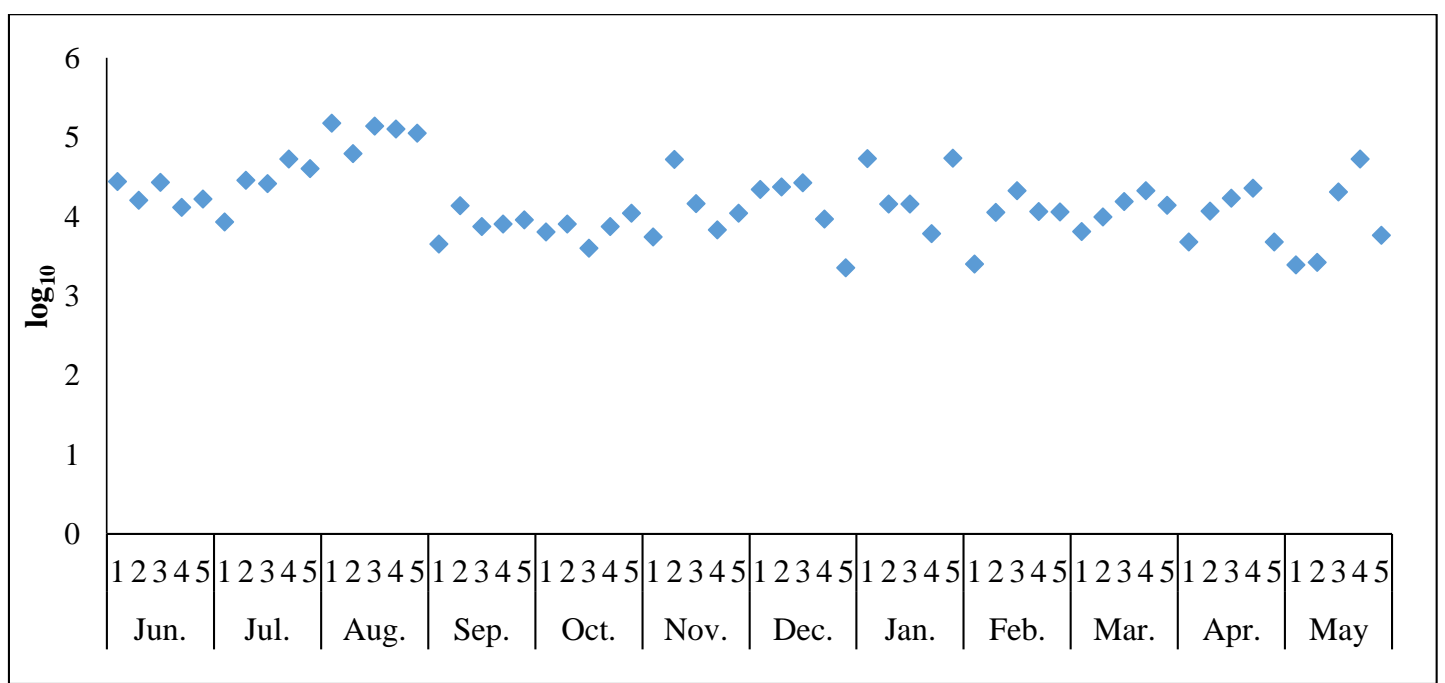

Figure 4. $22{ }^{\circ} \mathrm{C}$ Bacteria Count of water 


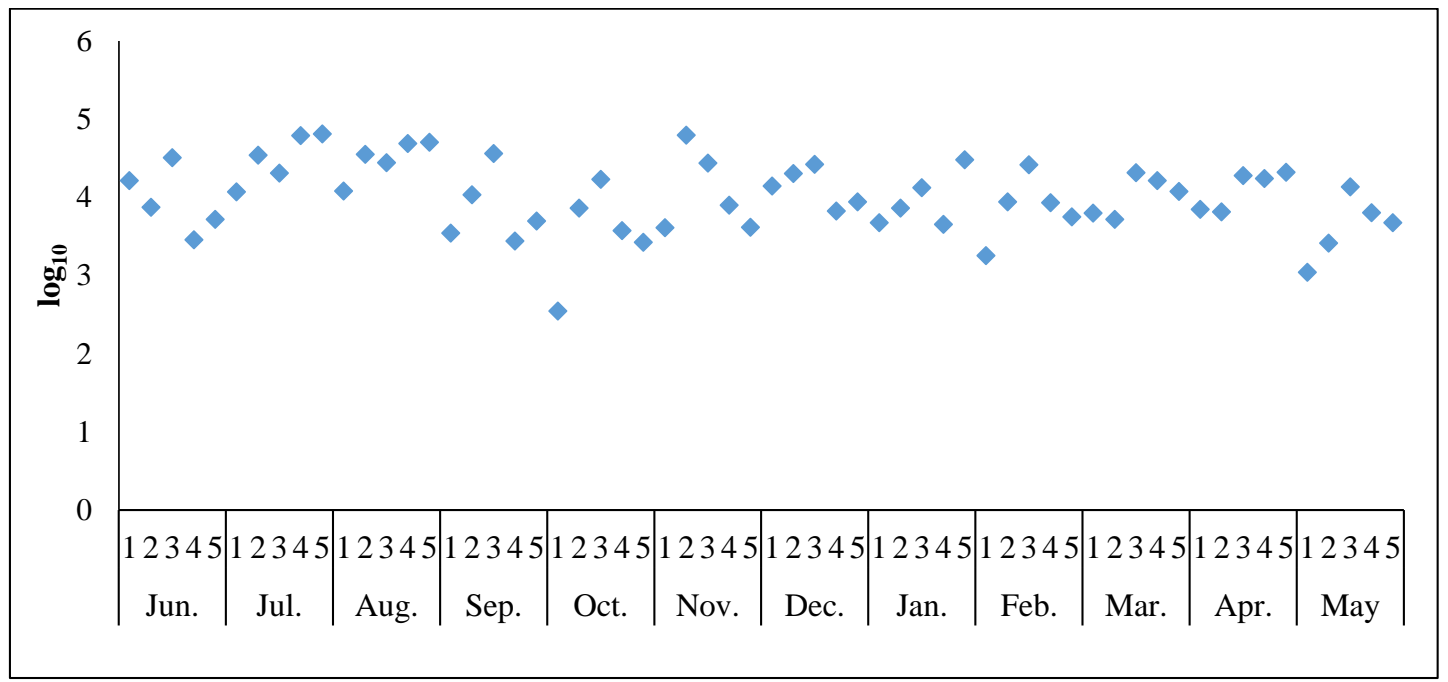

Figure 5. $37^{\circ} \mathrm{C}$ Bacteria Count of Water

Kirecci et al. (2017) had reported that $79 \%$ of the bacteria found in samples taken from different water sources in the province of Kahramanmaraş were identified as being E. coli (89). Tunçsiper (2017), in one bacteriological study conducted at Kizilca Creek, had reported that water samples had heavily contaminated with bacteria (Class IV- TWPCR 2004 -), as well as had pointed out that the condition of the lake poses a grave threat to drinking water, recreation, fish production, animal production, and irrigation. Gemci et al. (2016) had reported that coliform bacteria were not detected in either the surface water of either Pınarbaşı, Karasu, or Ayvalı. Bulut et al. (2016) had reported there being bacteriological contamination at Eğirdir Lake, whereupon researchers had pointed out that $T C$ bacteria count had increased in summer and autumn, as well as that $F C$ bacteria was detected at certain stations. Gürün and Altuğ (2013) had reported there being an extensive amount of bacteriological pollution at Güllük Port and Sarıçay Stream, and had stated that the bacteria at all of the stations had reached almost $90 \%$ during the summer months.

In the present study, $T C, F C$ and $F S$ rates were determined to $45 \%, 71.66 \%$ and $56.66 \%$, respectively, in the sixty surface water samples collected from Yağlıdere Stream, thus indicating bacteriological pollution. E. coli was also detected at high rates across almost all seasons. Across all seasons the TC count had reached upwards of 1100 MPN/100 $\mathrm{mL}$ and above. The only time this number fell was in the month of April. In addition, it was also found that the $F C$ count was $240 \mathrm{MPN} / 100 \mathrm{~mL}$ at almost all stations, and months, except for February. The changing $F S$ count has been determined to be in the range $0->240$. The abnormal crossing of reference ranges of at least one station each month paints a bleak picture for Yağlidere Stream, which is used for a variety of purposes such as drinking and irrigation. In particular, the density in the fecal origin bacterial population is much higher than the reference ranges, thus inviting a water-borne disease outbreak. The values obtained from this study are extremely high according to EPA and WHO standards (Table 2).

Table 2. Bacteriological Water Quality Parameters

\begin{tabular}{|c|c|c|c|c|}
\hline & RCWIHC 2013 & TS266 & EPA 2009 & WHO 2017 \\
\hline E. coli & $0 / 250 \mathrm{~mL}$ & $0 / 250 \mathrm{~mL}$ & 0 & 0 \\
\hline FS & $0 / 250 \mathrm{~mL}$ & $0 / 250 \mathrm{~mL}$ & 0 & \\
\hline TC & $0 / 250 \mathrm{~mL}$ & & 0 & 0 \\
\hline FC & & & 0 & 0 \\
\hline $22{ }^{\circ} \mathrm{C}$ & $20 / \mathrm{mL}^{*}$ & $100 / \mathrm{mL}^{*}$ & & \\
\hline $37^{\circ} \mathrm{C}$ & $5 / \mathrm{mL}^{*}$ & $20 / \mathrm{mL}^{*}$ & & \\
\hline
\end{tabular}

\section{Conclusion}

Consequently, the bacteriological water quality level is not suitable for aquatic life in the Yağlidere Stream. The largest contribution of this pollution had been established as being domestic waste as well was the waste of animal slaughterhouses, both of which were uncontrolled. When we compare our results with the literature, we have found that this pollution level only increases in the summer. The fact that $F C$, $F S$ and $E$. coli were detected at multiple stations in 
almost every month of the year indicates that the river has been heavily exposed to sewage-derived waste. What is more, when the number of bacteria in the water and sediment flora of the streamline is examined, we can see that the current human population in the unit area is also considerable, which is another indication that the organic load upon the stream is far too high. Therefore, if the local authorities do not take necessary measures, the outbreak of infectious water-borne diseases will unfortunately be inevitable.

\section{Acknowledgements}

This Master Thesis study was presented in 1 st international technological sciences and design symposium (ITESDES, 2018), 27-29 June 2018, Giresun-Turkey by poster presentation.

\section{References}

Akkan T. 2017. Antibiotic Resistance Case Study: Enterobacteriaceae isolated from Batlama Creek in Giresun, Turkey. Turkish Journal of Agriculture Food Science and Technology. 5(8):969-972. doi: 10.24925/turjaf.v5i8.969-972.1262

Akkan T, Kaya A, Dinçer S. 2015. Balık çiftliklerinin ekolojik tahribatına bir örnek: Bakterilerdeki antibiyotik dirençliliğine etkileri, İskenderun Körfezi. Anadolu Doğa Bilimleri Dergisi. 6(1):20-27.

Altuğ G, Çardak M, Türetken PSÇ, Şahin SK, Kalkan S. 2017. The Levels of Bio-Indicator Bacteria in the Fresh Water Resources of Eastern Anatolia Region of Turkey. Environmental Pollution and Protection. 2(3):117-123.

doi: 10.22606/epp.2017.23005

APHA 1992. Standard Methods for the Examination of Water and Wastewater, 18th ed. Washington: APHA 9 p.

Bulbul G, Elipek BC. 2017. Investigation of the effects of domestic waste on aquatic bacterial distribution in the Meric River (Edirne, Turkey). Biologija. 63(3):256-263.

Bulut C, Kubilay A, Akçimen U, Yener O. 2016. Eğirdir Gölü Mikrobiyoloji Kalitesinin Mevsimsel Değişiminin İncelenmesi. Isparta Süleyman Demirel Üniversitesi Fen Bilimleri Enstitüsü Dergisi. 20(1):50-53. doi: $10.19113 /$ sdufbed.92143

EPA 2009. United States Environmental Protection Agency. Edition of the drinking water standards and health advisories; [cited: 2018 Feb 24]. Available from https://nepis.epa.gov/Exe/ZyPDF.cgi/P1005P2B.PDF ?Dockey=P1005P2B.PDF

Gemci E, Akarsu S, Ziba CA, Dolaz M. 2016. Kahramanmaraş’taki Ayvalı yüzey suyu, Pınarbaşı ve Karasu kaynaklarının içme suyu kalitesinin araştırılması. KSU Mühendislik Bilimleri Dergisi. 19(1):21-24.

Gürün S, Altuğ G. 2013. Muğla Güllük Körfezi'nde bakteriyolojik kirlilik ve metabolik olarak aktif bakteri düzeyi. Paper presented at: Güllük Körfezi Bakteriyolojisi TÜBİTAK Proje Çalıştayı; Güllük, Muğla, Turkey.

Kireçci E, Uğuz TM, Aralı M. 2017. Kahramanmaraş İlindeki İçme, Kullanma ve Çevresel Suların Mikrobiyolojik Niteliğinin Membran Filtrasyon Sistemi İle Belirlenmesi. Kahramanmaraş KSÜ Doğa Bilimleri Dergisi. 20(1):20-24.

doi: 10.18016/ksujns.86250

Mutlu E, Uncumusaoğlu AA. 2016. Physicochemical Analysis of Water Quality of Brook Kuruçay. Turkish Journal of Agriculture - Food Science and Technology. 4(11):991-998. doi: 10.24925/turjaf.v4i11.991-998.946

Mutlu T, Verep B. 2018. The Water Quality of Streams Flowing Into South Eastern Black Sea Coasts In Terms Of Physico-Chemical Properties. Fresen Environ Bull. 27(5A):3752-3758.

Mutlu E, Kutlu B, Demir T. 2016. Assessment of Çinarli Stream (Hafik-Sivas)'s Water Quality via PhysicoChemical Methods. Turkish Journal of Agriculture Food Science and Technology. 4(4):267-278. doi: 10.24925/turjaf.v4i4.267-278.494

RCWIHC 2013. Regulation concerning water intended for human consumption. Ankara, Turkey: The Turkish Official Gazette. Report No.: 28580.

TS266 2005. Water intended for human consumption. Ankara, Turkey: Turkish Standards Institute (TSE). Report No.: 13.060.20.

Sipahi N, Mutlu C, Akkan T. 2013. Giresun İlinde tüketime sunulan bazı balıklardan izole edilen Enterobacteriaceae üyelerinin antibiyotik ve ağır metal dirençlilik düzeyleri. Gıda. 38(6):343-349.

doi: 10.5505/gida.2013.55264

Tunçsiper B. 2017. Akkaya Barajını Besleyen Kızılca (Karasu) Deresindeki Bakteriyolojik Kirlenmenin İncelenmesi ve Kirliliğin Azaltılması İçin Çözüm Önerileri. Tekirdağ Ziraat Fakültesi Dergisi. 14(1):28-37.

TWPCR 2004. Turkish Water Pollution Control Regulation. Ankara, Turkey: The Turkish Official Gazette. Report No.: 25687

Verep B, Mutlu T, Çakır V, Aydın G. 2017. Derepazarı Deresinin (Rize-TÜRKIYYE) Fiziko-Kimyasal Su Kalitesinin Belirlenmesi ve Bazı Su Kalite Standartlarına Göre Değerlendirilmesi. Journal of Anatolian Environmental and Animal Sciences. $1(2): 19-22$.

WHO 2017. World Health Organization. Guidelines for Drinking- Water Quality; [cited 2018 Feb 03]. Available from https://apps.who.int/iris/bitstream/handle/10665/4458 4/9789241548151_eng.pdf?sequence=1.

Yildirim, Y, Vurma HT. 2017. Antibiotic Resistance Profiles of the Bacteria Isolated from some Finfish Species in Iskenderun Bay, (Northeastern Mediterranean Sea), Turkey. Pakistan J. Zool. 49(4):1353-1358. doi: 10.17582/journal.pjz/2017.49.4.1353.1358 